\title{
ANÁLISIS SEMIOLÓGICO DEL MITO COMO PATRIMO- NIO COLECTIVO E INDIVIDUAL EN CUATRO NIVELES DE INTERPRETACIÓN
}

Semiological analysis of Myth as a collective and individual heritage in four interpretation levels

José Ochoa

Investigador independiente

jose.ochoa@gmail.com

Julián García

Universidad Politécnica Salesiana del Ecuador, Docente Investigador www.ups.edu.ec / jgarcial@ups.edu.ec

Fecha de recepción del artículo: 18/07/2017

Fecha de aceptación definitiva: 15/12/2017 


\section{Resumen}

El análisis del mito lo fosiliza y lo desconecta de su función primigenia y su significado más profundo. A partir del testimonio de los aborígenes australianos, se han identificado cuatro posibles niveles de significado del mito. En este trabajo, utilizando la metodología semiológica, nos proponemos el objetivo de ver si este proceso de interpretación puede haber sido un denominador común en todas las culturas que, en el mito, tienen un patrimonio colectivo inmaterial. Proponemos una denominación a estos niveles de análisis y significado, aportando ejemplos de culturas, épocas y territorios muy distantes. El resultado es una verificación del nivel más íntimo de significado del mito, conscientes de que los métodos científicos siempre nos mantendrán alejados de la capa más personal y viva del mito, la que constituye el patrimonio individual.

Palabras clave: Mito, universal cultural, patrimonio cultural inmaterial, semiología, epistemología.

\section{Abstract}

Myth's analysis fossilizes it and disconnects it from its original function and its deeper meaning. Starting from the testimony of the Australian Aboriginal People have been identified four possible levels of meaning for myths, and using semiological method, we have as a goal to find out if this interpretation process could be common to every culture having in the myth an immaterial collective heritage. We propose a name for these levels of analysis and meaning, providing examples from various cultures, from diverse times and territories. The result is a verification of the most intimate level in the meaning of myth, being aware that scientific methods always will keep us away from the more personal and living layer of myth interpretation, the one that constitutes the individual patrimony.

Key words: Myth, universal cultural, intangible cultural heritage, semiology, epistemology 


\section{Introducción: Significado y funciones del mito}

Si hay un concepto difícil de acotar es el de 'mito'. Un término usado en diferentes acepciones y que tiene connotaciones culturales muy diferentes entre unos y otros grupos humanos. Una noción que ha sido utilizada y hasta tergiversada en múltiples ocasiones. El filósofo A.F. Losev (1998, p. 64) primero lo define en negativo: no es mentira ni ficción, sino una categoría de la conciencia que es lógicamente necesaria; no es esquema ni alegoría, sino símbolo; no es una obra poética, sino una abstracción primitivo-biológica de la relación entre el sujeto $\mathrm{y}$ el objeto.

Según la Filosofía de las formas simbólicas de Cassirer, Quezada (2007, pp. 20-22), el mito "está en el lenguaje y al mismo tiempo más allá del lenguaje" y es "una filosofía del discurso" (de su forma primigenia de ser discurso), es "producto de una tensión entre un modo originario de aprehender y un modo originario de interpretar" y, por tanto, es "esencialmente semiosis".

Mientras unos autores se centran en la búsqueda de patrones, siguiendo el método estructuralista, dando importancia a lo territorial y acuñando el término 'topomítico' (Chaparro, 2013, p. 23), otros se apartan marcadamente de todo intento de sistematizar, abominando del concepto de 'mitema' (López Eire, 2012, p. 47) en torno al cual, Lévi-Strauss desarrolló su trabajo. El antropólogo francés aplicó la estructura lingüística a la estructura mítica, buscando unidades de significado que pudieran componerse y ser analizadas como una sintaxis de la narración mítica. Para mitólogos como López Eire es imposible aplicar este enfoque de una manera consistente a los mitos y, por lo tanto, no es un esquema válido de análisis, porque el mito es como el lenguaje, en tanto, como un acto de habla, como discurso, no como una estructura morfosintácica.

Historiadores, filólogos, sociólogos, filósofos, literatos, antropólogos y especialistas de otras áreas han rastreado funciones que pueden desempeñar los mitos. Podríamos decir que el mito serviría para:

- Entretener: narrar una trama.

- Imaginar: dar cauce a la fantasía, ensoñación, proporcionar una proyección más allá de la naturaleza.

- Entender: función gnoseológica. Existe un razonamiento causaefecto en el mito. Para Cassirer, el mito es objetivo en la medida en que sea reconocido como factor de liberación de la inhibición pasiva ante la impresión sensible, y permita progresar hacia la creación de un mundo propio configurado de acuerdo con un principio espiritual. Por tanto, es gnoseológico. El pueblo primitivo está movido por una necesidad o un deseo de comprender el mundo que le circunda, su naturaleza y la socie- 
dad en la que vive. Y lo hace por medios intelectuales (como un filósofo o un científico), dice Lévi-Strauss (1964). El mito tiene una función conciliadora de contradicciones o conflictos binarios, de opuestos (enfoque estructuralista a ultranza). Sirve para resolver problemas de tipo sociológico o psicológico. Genera la existencia de un orden (interno y externo a cada grupo humano).

\section{- Enseñar, educar:}

- Con una función explicativa de fenómenos vinculados a la realidad física y natural, aunque lo hace "exponiendo los motivos", no dando explicaciones (no hay violencia de concepto, no hay dialéctica). Expone los principios, no sus causas. Por tanto, "es 'arjai' y no 'aitía'", como dice De Cuenca (1974, p. 18).

- Con una función edificante: enseñanza moral, tabúes, filosofía, principios de vida. Por supuesto, desde un punto de vista positivo porque, de hecho, el cuento amoral supone un enfoque creativo que solo aparece en una sociedad muy avanzada. En este sentido, conviene anotar que la moraleja es más propia del cuento y de las culturas de Occidente y Oriente.

- Emocionar: en este caso, la finalidad no es tanto la de ofrecer pruebas filosóficas sino más bien la de producir una respuesta emocional frente a un aspecto de nuestra experiencia.

- Cohesionar: Proporcionar un sentimiento de pertenencia, un valor identitario. Sirve para reforzar un sentimiento religioso, sacralizar un rito o un culto.

- Ejemplificar: Dar modelos que contribuyen al mantenimiento de la cohesión social y cultural.

\section{El análisis del mito}

Si el mito puede tener funciones tan variadas, ¿cómo podemos afrontar su análisis de una forma apropiada? Para esta pregunta, en los dos últimos siglos, ha habido diversas respuestas y se ha propuesto múltiples clasificaciones, y todas contemplan el componente explicativo del origen de las cosas, como la propuesta por Almeida (2014, pp. 21-22). Siguiendo a Geofrey Kirk (1976), diríamos que hay variadas tipologías con funciones distintas. Es decir, que "no puede haber una definición común, una teoría monolítica, ninguna respuesta sencilla a todos los problemas e incertidumbres que plantean los mitos" (Kirk, 1984, p. 32). Kirk enumera las que denomina "cinco teorías monolíticas", a las que añadiremos una que tampoco era plenamente de su gusto (pp. 58-76).

1. Naturalista: el mito expresa fenómenos naturales, lo cual implicaría que todos son explicables. Ni todos los temas tienen la naturaleza como 
referente, ni todos los mitos son explicables (hay una esencia poética o mística que no se puede reducir a lógica).

2. Etiológica: el mito ofrece una causa o explicación de algo que pertenece al mundo real, a modo de protociencia han dicho algunos. Pero pueden ser explicativos de maneras muy diferentes y a niveles muy distintos.

3. Estatutaria: el mito es un estatuto de las costumbres, instituciones o creencias. Tiene, pues, una finalidad práctica y sirve para establecer un precedente de cada estructura social como señaló Bronislaw Malinowski, al pretender realizar un estudio de los mitos en acción.

4. Evocadora: incluso nostálgica del pasado. Se hace con el mito referencia a la era de la creación, a la época áurea, y de alguna forma permite revivirla y mantener el orden originario, primeval (Mircea Eliade). En los mitos australianos se da vida a la 'Era de los Sueños' o al 'Tiempo del Sueño Eterno', se proyectan y actualizan en el presente.

5. Ritual: el mito es soporte del rito (Robertson Smith y Frazer). Mito y rito son uno y lo mismo (Leach). Para Kirk, los mitos heroicos serían un buen ejemplo de que esto no es una afirmación de validez universal (aunque hay excepciones: Teseo en el laberinto pudo tener origen ritual).

6. Psíquica: el mito es un producto de la psique, particularmente vinculado con el inconsciente y los sueños. Los mitos son, en cierto modo, el pensamiento de los pueblos expresado en sus sueños (Freud). El inconsciente actúa en el sueño con la función de condensar el material de la experiencia del día, desplazar sus elementos representándolos en símbolos e imágenes.

Habría una opción adicional que podríamos llamar multifuncionalista. Para Kirk, la teoría de análisis de Percy Cohen era la más válida (Kirk, 1984, p. 33). Según ella, pueden coexistir diferentes motivaciones: de la implicación social al carácter psicológico. Este método permite flexibilidad para analizar el complejo fenómeno de los mitos, pero corre el riesgo de que el analista traslade al mito su visión relativista.

Para López Eire (2012), por ejemplo, combativo contra el estructuralismo, el mito es un acto del habla, es "lenguaje concebido como acción en una comunidad político-social" (p. 32). Se trata de "un discurso de alguien a sus conciudadanos", que se produce en un contexto, una intención y unas coordenadas de tiempo y espacio específicas (p. 50).

No obstante, volviendo a Losev (1998), podemos anotar que el mito es realidad material vitalmente sentida y creada, "es una relación recíproca viva entre el sujeto y el objeto, que contiene su propia veracidad, autenticidad (...), su estructura básica" (pp. 64-65). Esto nos lleva al plano subjetivo, a la experiencia indivi- 
dual, al patrimonio personal de lo sentido de forma íntima. Estaremos entrando entonces en la percepción del mito desde dentro, como "la intelección de la vida dada simbólicamente".

Intentaremos ahora desentrañar el mecanismo interno que podría utilizar el mito para moverse entre ese doble plano de lo colectivo y lo individual, del patrimonio inmaterial de una cultura y el proceso vital de un individuo.

\section{Propuesta metodológica: Interpretación del mito en $\mathbf{4}$ niveles}

Todos estos enfoques tienen en común que la visión del mito procede de cómo la ciencia interpreta de forma externa el fenómeno del mito. Se trata de una concepción del saber mítico como patrimonio inmaterial de una sociedad (como lo entiende la UNESCO en https://ich.unesco.org/es/tradiciones-yexpresiones-orales-00053), de una cultura que se reconoce en sus narraciones. No obstante, no deja de ser una visión desde fuera, no una mirada desde quien "vive" el mito, porque las sociedades que han adoptado el desarrollo científico tienen los mitos fosilizados. Sin embargo, entre los aborígenes australianos hay cuatro niveles claros de interpretación del mito, niveles de significado para los miembros de su sociedad, para los que escuchan el mito de la voz de los transmisores de su saber colectivo, como explican Sveiby y Skuthorpe (2006), con un ejemplo de la población aborigen australiana Nhunggabarra.

Por darle un nombre que las diferencie de los análisis inventariados por Kirk, quizá podríamos llamar a esta interpretación significativa, porque se refiere al significado interno y se trata de un camino de aprendizaje, de un desarrollo del individuo. A continuación, a esos cuatro niveles $(\mathrm{N})$ de significación les vamos a asignar aquí una denominación:

1. Etiológico: hace referencia al mundo físico y natural, responde a preguntas muchas veces tachadas de infantiles. Aborda los porqués, permite un mayor grado de dramatización, tienen una justificación que es explícita, y consienten una observación directa. Este nivel es el más vinculado a la parte dramatizada de transmisión de la narración (gestos, movimientos, danza y voces).

2. Sociológico-conductual: alude a comportamientos, a relaciones con la comunidad; forma parte del proceso educativo, del camino a la madurez; implica conocimientos previos y hay que estar iniciado de alguna forma para captarlo.

3. Sistémico: toma la dimensión ecológica, convivencial. Implica una percepción holística de la realidad circundante. 
4. Espiritual: tiene carácter simbólico e interpretativo. Es vivencial, supone una experiencia directa del mito por parte del propio individuo (no forzosamente vinculado a un rito, aunque exista esta asociación).

Los niveles 3 y 4 de este esquema semiológico nos ofrecen una oportunidad nueva de estudio. El análisis del mito como mitografía, como estructura, como función, aplican una mirada desde afuera, mientras que la mirada sistémica y espiritual intentan aproximarse a la interpretación interna del mito, a cómo lo viven las culturas que todavía los utilizan como herramienta cognitiva.

Tomemos como ejemplo el mito de aborígenes australianos que utilizan los mencionados autores: la narración tradicional de la grulla y el cuervo (Sveiby 2006, pp. 42-43).

Garraagaa, la grulla, era una gran pescadora. [N2a] Podría pescar muchos peces, sacándolos con sus partas de debajo de los troncos de los riachuelos. [N3a] Un día, cuando tenía un buen montón de peces en la orilla del río, [N3b] Waan, el cuervo, que por aquél entonces era blanco, se acercó y le pidió a la grulla que le diera algún pez. [N3c]

La grulla le dijo al cuervo que esperara a que el pescado estuviera cocinado, [N2b, c] pero el cuervo estaba hambriento e impaciente. [N2d] No hacía más que molestar a la grulla, que le decía que esperara.

En un momento dado, la grulla le dio la espalda. El cuervo se acercó sigilosamente y estaba a punto de robarle un pez, cuando la grulla lo vio, agarró un pez y le golpeó con él en los ojos.

El cuervo se quedó ciego durante unos minutos, cayó sobre la hierba quemada que había alrededor del fuego y se revolcó de dolor sobre ella. Cuando se levantó, sus ojos eran blancos y el resto de él negro, [N4a] como hemos conocido siempre a los cuervos. [N1a]

El cuervo estaba decidido a vengarse. [N3d] Esperó la ocasión, hasta que un día vio a la grulla dormida boca arriba con la boca completamente abierta. [N4b] Se deslizó hasta ella y le metió una espina de pescado en el fondo de la lengua.

La grulla se despertó y cuando abrió la boca para bostezar se dio cuenta de que la tenía bloqueada. Trató de sacarse la espina de la garganta y en el esfuerzo dejó escapar un extraño ruido estridente. "gah-rah-gah, 
gah-rah-gah". Pero la espina no se movió. Aún hoy, único sonido que puede emitir una grulla es este, el que le da nombre. [N1b]

En el texto hemos introducido un sencillo código para indicar las interpretaciones según los niveles $(\mathrm{N})$ antes mencionados:

- N1a: Explica el color del cuervo (ojos y plumas).

- N1b: Explica el nombre onomatopéyico de la grulla y por qué grazna así.

- N2a: Comparte el conocimiento: una habilidad personal no debe explotarse en beneficio propio. El conocimiento que no se comparte, muere.

- N2b: No hay que imponer el propio punto de vista, porque cada uno tiene su verdad. Si no, estoy abusando de mi poder.

- N2c: No hay que acumular roles. El trabajo hay que repartirlo, porque involucra a los demás, conduce a trabajar en equipo, y reduce el riesgo de monopolio de conocimiento

- N2d: Quien tiene un conocimiento, tiene una responsabilidad. Hay que pensar en las necesidades de todos.

- N3a: No permanezcas en un mismo lugar, muévete en función de las estaciones para aprovechar los recursos que surgen de la naturaleza.

- N3b: No agotes las reservas, deja que se regeneren.

- N3c: Compórtate con responsabilidad hacia otras comunidades.

- N3d: Castígate solo a ti. Solo los tuyos te pueden castigar (lo que evita las venganzas).

- N4a: Uno puede cambiar de apariencia y puede transformarse.

- N4b: Uno puede viajar en sueños, encontrarse con un ancestro o un animal totémico. Si duermes bocarriba, expones tu cuerpo y por la boca pueden entrar espíritus.

\section{El mito como vehículo de conocimiento}

Lo verdaderamente interesante de una narración como la de la grulla y el cuervo, es observarla como un instrumento de adquisición de conocimiento, como un proceso de aprendizaje; es decir, como un descubrimiento.

El mito se cuenta en el entorno de la comunidad una y otra vez y cada oyente tiene un nivel previo de conocimiento, lo que le faculta de condiciones para ir 
avanzado en él. Para llegar al segundo nivel [N2], el joven de la comunidad debe ser guiado por alguien que le apoye, no se trata de que reciba las claves para entenderlo, sino de que vaya adquiriendo las condiciones para encontrarlas, para hacer su lectura interior. Por otro lado, el último nivel [N4] no suele estar al alcance de todos.

En su perspectiva desde la lingüística pragmática, López Eire (2012, p. 33) afirma que siempre que alguien habla o cuenta algo lo hace con un propósito y, en ese proceso, el mito cumple una función de cohesión político-social (52). Esta visión pone el foco en el emisor (intención, contexto) y no tanto en el receptor. Desde el punto de vista de quien recibe el mito, hay una experiencia de aprendizaje. Los mitos pasan entonces a ser contenedores de conocimiento.

Respecto a los mitos griegos, Grote dijo (1864) que "constituían todo el fondo intelectual de la época a la que pertenecían", que "eran parte integrante de una estructura que constituye el pensamiento humano de una época" (p. VIII).

El mito es "alusivo por naturaleza y su modo de referencia es tangencial" (Kirk 1973, pp. 61-62). No pretende ser algo completo, acabado o intenta seguir una secuencia específica ni totalmente lógica. No sería una especie de "ciencia primitiva" como creía Lang. Al contrario, tiene un enfoque totalitarista: un modo de pensar que, si no comprende todo, no puede explicar nada. Para LéviStrauss, así no se alcanza el éxito en el dominio de la naturaleza. En su concepto del 'pensamiento salvaje' o la 'lógica de lo concreto' no se emplea abstracción alguna, sino que se confía solo en los sentidos. Los pueblos ágrafos usan un método acumulativo, no deductivo. Este enfoque afirma que el hombre primitivo tiene la ilusión de que entiende todo, mientras el mito fracasa en su objetivo de proporcionar al hombre un mayor poder material sobre el medio. Por el contrario, la ciencia divide la realidad en tantas partes como sea necesario para resolverla.

Por el contrario, Morin (2007, pp. 109-110) nos recuerda que lo complejo implica una visión holística, que trata tanto el conjunto como sus partes. La especialización en la cultura occidental nos ha llevado a separarnos de la percepción de los problemas complejos. Los pueblos originarios tienen una visión que entiende "el todo", el conjunto; y que no pretende dominar, sino vivir la naturaleza.

El famoso trabajo de Castaneda (1974) intenta explicar el fenómeno desde dentro y nos hace ver que, a pesar de todas sus diferencias de percepción, posee su propia lógica interna. 


\section{Una hipótesis prueba a prueba}

¿Qué ocurriría si este esquema de interpretación en cuatro niveles fuera válido para cualquier mito en cualquier cultura? En ese caso, podríamos estar ante un arquetipo funcional, una especie de artefacto cognitivo común al ser humano. Es decir, podría ser un universal cultural humano que hemos olvidado, desatendido o descartado, que ha quedado relegado a unas pocas culturas donde sobrevive, pero que siempre estuvo presente.

La denominación "universal humano" fue acuñada por el antropólogo Donald Brown (1991) para referirse a aspectos de la cultura, sociedad, lenguaje, comportamiento y psique para las que no se encuentran excepciones en ninguna cultura en toda la humanidad. En esa categoría estarían la risa, el ritmo, el conflicto, la ley y la norma, la poesía, el rito. También están el símbolo y la metáfora, entre otros patrones o modelos de comunicación y aprendizaje. Brown incluye al mito entre los universales humanos y nuestra hipótesis sería que la estructura interpretativa por niveles también fuera uno de ellos sin excepción.

No es fácil demostrarlo ni es el objeto de este trabajo intentarlo, pero, si se tratara de un universal humano, los mitos de todas las culturas podrían llegar a tener esas cuatro capas de interpretación y podríamos releerlos bajo esa óptica. Lo universal no sería que todos los mitos tuvieran los cuatro niveles, sino que todas las culturas podrían tener mitos que llegaran a los niveles más abstractos y profundos de interpretación [ 3 y 4 ] como forma de acceder al conocimiento a través de ese proceso.

Para ello vamos a ensayar el esquema semiológico propuesto a ejemplos de mitos que proceden de culturas, épocas y territorios muy distantes.

Apliquémoslo a una narración de un pueblo originario del que quedan pocos habitantes, los záparas del Ecuador. La historia de Tsitsanu, como está recogida por Ushigua (2006) en el libro ilustrado por Alfonso Toaquiza, tiene todos los elementos de la narración del viaje del personaje que es una especie de Prometeo amazónico, que va enseñando a comer alimentos cocidos gracias al fuego, a parir si necesidad de abrir el vientre de la madre, y que un momento determinado: 
(...) llegó donde vivían los tigres y se encontró con una tigresa anciana que tenía su hijo muy enfermo. Ella le pidió que curara a su hijo. Tsitsanu no sabía curar nada, pero hizo lo posible para sanar al niño: le sacó las espinas, porque el niño se había comido un puerco espín. Después de un rato llegaron los otros tigres y querían comerse a Tsitsanu; pero la tigresa les dijo que no se lo comieran, porque él curó a su hijo; entonces los tigres lo dejaron libre. [N2a]

Todos los tigres se reunieron para agradecer por la ayuda que les brindó Tsitsanu. Entre ellos, acordaron entregarle su lanza, en la que estaba el espíritu del tigre, y le dijeron que solamente Tsitsanu debía tenerla. [N2b]

Tsitsanu se quedó solo nuevamente y se fue muy lejos por el camino. (...) Entonces Tsitsanu emprendió el regreso a su casa; pidiendo a una tórtola que lo guiara. La tórtola le dijo a Tsitsanu: -A mí me decías que me ibas a coger para hacer un maito para comer, estoy cansada de escuchar eso; de hoy en adelante no quiero que me digas así- advirtió. Entonces, la tórtola lo llevó al camino donde Tsitsanu se perdió al comienzo y ella se alejó volando. [N3a]

(...) Tsitsanu llegó justo el día señalado y disfrutaron de la fiesta.

Tsitsanu llevó su lanza y explicó que nadie tenía que cogerla sin su permiso. [N2a] Un día un hombre loco llegó a la casa de Tsitsanu y se llevó la lanza, mientras Tsitsanu estaba con su esposa en la chacra. Ese hombre loco se llevó la lanza al monte. [N1a] Paró a defecar, y la lanza se convirtió en tigre y se comió al hombre. La lanza, con un gran viento y truenos, regresó a sus dueños originales; pero su poder se quedó con Tsitsanu. [N4a]

Aplicando el esquema de los cuatro niveles, a los fragmentos que leemos al final de la narración, podríamos encontrar:

- N1a: Además de todos los elementos etiológicos que aparecen en la parte no citada de la narración, podemos asignar a este nivel al hombre que roba la lanza a pesar de las advertencias y que solo puede ser calificado de loco. 
- N2a: La actividad altruista de ayuda se ve recompensada por una actitud benévola para con la persona que se muestra generosa, a pesar de la fiereza natural del tigre.

- N2b: En las culturas amazónicas, la reciprocidad es un elemento esencial de la convivencia.

- N3a: La relación de Tsitsanu con la tórtola (que se establece al inicio del relato, en la parte que no hemos citado) implica un respeto a los animales de la selva. Una relación de coexistencia en plano de igualdad (similar al pasaje de los tigres) que es la que permite a Tsitsanu regresar junto a los suyos.

- N4a: El poder del tigre no es solo un símbolo abstracto. En la narración está representado en la lanza de Tsitsanu, pero más allá del objeto, la valentía, la fuerza del cazador que "se queda" con Tsitsanu va más allá del propio símbolo o del atributo de la lanza. No es difícil imaginar a un joven zápara viviendo el mito de Tsitsanu en sus experiencias de caza, sintiendo en su interior la fuerza del tigre, como tantas veces la escuchó en el mito.

\section{Aplicación a un mito griego clásico}

Muchas personas, cuando oyen hablar de mitos, piensan en la mitología grecolatina, que tantas imágenes ha proporcionado a la literatura universal. ¿Podríamos aplicar este esquema a los mitos clásicos? Probemos con el mito de Deméter y Perséfone.

Un día Perséfone, hija de Deméter y Zeus, estaba recogiendo flores en la pradera de Nisa, junto a las ninfas hijas de Océano. Se quedó admirada al ver un hermoso narciso que Gea, instigada por Zeus, había hecho brotar allí. Entonces la tierra se abrió y apareció Hades, que se llevó a la joven a las mansiones subterráneas.

Perséfone grita llamando a su madre. Nadie escucha sus gritos, a excepción de Deméter, [N4a] que se viste de luto y busca a su hija durante nueve días y nueve noches, [N1a] alumbrándose con una antorcha.

Al amanecer del décimo día encuentra a Hécate, quien le dice que ha visto pasar a su hija sobre un carro resplandeciente, pero que no ha podido ver al raptor. Sin embargo, le sugiere que pregunte a Helio. Este le cuenta lo sucedido, y Deméter se enfurece al entender la connivencia de Zeus en el rapto y abandona el Olim- 
po. Se transforma en una anciana y baja a la tierra. [N1b]

Llega a Eleusis, donde reina Céleo, y en el camino se sienta a descansar en el pozo de las doncellas, a la sombra de un olivo. Allí acuden por agua las hijas de Céleo, que le preguntan quién es y por qué está afligida. Deméter oculta su verdadera identidad y se ofrece como sirvienta. Las hijas piden a Metanira, su madre, que la acepte en su casa. Deméter levanta su velo y la expresión divina asoma a su envejecido rostro. Entonces Metanira, impresionada, le cede su asiento, [N2a] pero la diosa permanece triste por la pérdida de su hija hasta que la criada Yambe la hacer reír con sus chistes obscenos. La reina le ofrece vino, pero la diosa pide que le den una mezcla de cebada, agua y plantas olorosas. [N2b]

Metanira le encarga que sea la nodriza de su hijo Demofonte, y Deméter decide hacerlo inmortal, para lo cual lo unge con ambrosía soplándole dulcemente y teniéndolo en su regazo; por las noches lo pone al fuego para que se queme poco a poco lo que tiene de mortal.

Una noche, Metanira se asusta al ver a su hijo en el fuego y da un grito. [N2c] Deméter se enfada, descubre su personalidad y desiste de hacer al niño inmortal. Además, ordena que se construya en ese lugar un templo para poder enseñar a los hombres los ritos expiatorios. [N1c]

Una vez hecho el templo, Deméter, desconsolada todavía por la pérdida de su hija, se niega a dar la bendición a los campos. [N1d] Todo está sin vida, y el género humano a punto de extinguirse. Entonces Zeus manda primero a su mensajera Iris y, después, a todos los dioses para que hagan volver a Deméter al Olimpo y para que devuelva la fertilidad a la tierra. Pero ella se niega.

Zeus decide mandar a Hermes para que inste a Hades a que devuelva a Perséfone. [N3a] Hades, para que no sea posible el regreso de Perséfone y quede ligada a las mansiones subterráneas, le da a comer un grano de granada. [N2d] Acompañados de Hermes, dirige a Perséfone al encuentro con Deméter, quien se entera de que su hija ha comido un fruto en las moradas subterráneas y ha de cumplirse lo que marca el destino. [N4b] Perséfone debe permanecer un tercio del año con 
su esposo en las moradas infernales, y el resto puede vivir con su madre en el Olimpo. [N4c]

A Deméter y Perséfone se unen Hécate y Rea, a la que ha enviado Zeus para que las condujera al Olimpo, pero antes Deméter enseña a los príncipes de Eleusis (Céleo, Diocles, Eumolpo y Triptólemo), los ritos sagrados con que quiere ser honrada y los secretos de la agricultura. [N1e]

Hay muchos elementos que podríamos rastrear, incluso después de siglos transcurridos desde el origen de la narración a su fijación por escrito en los Poemas homéricos como los podemos leer en la traducción española de Bernabé (1978). Prestemos atención a los siguientes:

- N1a: Se nos escapa el significado del número nueve en esta narración, pero sin duda lo tuvo para quienes la escuchaban.

- N1b: El componente de transformación es omnipresente en el mito grecolatino, hasta el punto que Ovidio los recopiló en Las metamorfosis.

- N1c: Otro elemento común a muchos mitos griegos es que suponen la fundación de una ciudad, de un templo o de una institución (el tribunal de Areópago en el mito de Orestes).

- N1d: La negativa de Deméter a bendecir los cambios implica una interrupción de las cosechas, igual que el regreso de su hija una vez al año supone una instauración de las estaciones y de los ciclos agrícolas.

- N1e: El mito traza también el comienzo de la agricultura, aunque de una forma no coherente, dado que antes se dice que se habían parado las cosechas. (No entraremos aquí en la causa de esta incongruencia interna de la narración, debida seguramente a un proceso de transmisión desde el Próximo Oriente Antiguo, donde los periodos de sequía imprevisibles podían interrumpir el ciclo agrícola mediterráneo facilitado por estaciones de ciclo previsible y estable).

- N2a: Ante la presencia de un dios, el respeto debido es clave en la cultura griega. Si falta ese respeto es por soberbia (hybris), que conllevará un castigo (némesis).

- N2b: La mezcla de ingredientes que pide la diosa para su bebida está vinculada a los ritos de los misterios de Eleusis, donde se ingería esa bebida.

- N2c: Asustarse por lo que uno desconoce y tomar decisiones desde esa ignorancia lleva a grandes males. El mundo no terrenal resulta inescrutable para alguien no iniciado. 
- N2d: El mundo ultraterreno también está sujeto a reglas y normas.

- N3a: Tal como nos ha llegado no se reconoce mucho significado de este nivel de interpretación, aunque seguramente lo tuvo. Quizá el hecho de que el equilibrio de fuerzas en el mundo divino implica un esfuerzo negociador y técnicas de influencia que también los humanos deben desplegar en sus relaciones sociales.

- N4a: La vinculación madre-hija como instinto natural, tiene que ver también con el sustrato de un culto a la fertilidad preexistente en Eleusis al menos desde época micénica.

- N4b: En los misterios eleusinos el contenido simbólico fue aumentando gradualmente y se pasó de los rituales de renovación de la cosecha a rituales de renovación de los propios iniciados y de la vida después de la muerte.

- N4c: Quien tiene contacto con el inframundo queda vinculado a él de alguna forma.

La instauración de los misterios eleusinos, que arranca del mito de Deméter y Perséfone, nos introduce en el asunto de la vinculación directa que existe entre los mitos y los ritos. "El rito pone en práctica la misma experiencia de lo 'divino' como poder suprahumano" (Vernant 1991, pp. 24-28).

El culto es utilitario, pero no menos simbólico. Una ceremonia se atiene a un argumento cuyos episodios están tan estrictamente ordenados, tan cargados de significado como las secuencias de una narración. El mito se repite para que sea cierto lo que narra. $Y$ se hace en momentos concretos, vinculados a una liturgia, a un rito, a una fiesta o celebración. Hay ritos de paso, iniciáticos, en los que el mito cumple una función 'liminal', es decir, de transición a través de un umbral.

\section{El mito se somete a análisis}

Pero ¿qué le ocurrió al mito griego para que fuera perdiendo los significados que, en el ejemplo de Deméter, perduran vinculados a los ritos de los misterios de Eleusis? Básicamente que se convirtió en literatura. Tenemos la fortuna de contar con excelsos poemas, obras maestras de teatro y narraciones que han influido en siglos de literatura, pero la cultura griega perdió su conexión con los niveles más vivenciales y experienciales de interpretación de sus mitos. 
Por otro lado, los procesos racionales de análisis en ciencias humanas han llevado a un pormenorizado trabajo de inventario y catalogación. En Grecia, esa recopilación y comparación de las tradiciones orales se hizo por iniciativa de las ciudades, de santuarios (crónicas) y de los mitógrafos helenísticos como Apolodoro o Calímaco.

El mito pronto se sometió también a crítica. Los griegos, en su construcción filosófica y científica de la racionalidad, pusieron en entredicho la veracidad de los mitos. El historiador, el filósofo privan a la fábula de la capacidad de hablar de forma auténtica de lo divino, de lo trascendente.

Para Lévi-Bruhl el pensamiento prelógico es inferior intelectual y espiritualmente. El hombre primitivo está dotado de cualidades diferentes a las del hombre civilizado. Sus teorías han sido superadas hace tiempo en las ciencias sociales, pero no en la opinión pública, donde sigue existiendo el prejuicio de que el pensamiento racional civilizado es superior al pensamiento que Lévi-Strauss denomina 'salvaje'. Para él, se trata de una forma de pensamiento perfectamente coherente, "supone leyes operantes a un nivel más profundo". El pensamiento mítico no es inferior al pensamiento racional. Ambos son válidos. Ambos manejan categorías lógicas, aunque el mito use reglas discursivas diferentes a las de la ciencia (Jensen). Como dice De Cuenca, "el mito es lo concreto intuitivo, la ciencia es lo abstracto racional" (1974, p. 69). La clásica contraposición entre la explicación racional y el mito queda invalidada, si tenemos en consideración la figura de la "elasticidad semántica" de muchos conceptos que el mito maneja (Lloyd 2012, p. 85).

Una de las características que perdió el mito en esa transición fue la oralidad, elemento clave en la transmisión del saber en las culturas ágrafas o en las que no se utiliza la escritura excepto ocasionalmente para fines utilitarios o administrativos. En la oralidad, la autoría es anónima. No existe un creador individual, porque la obra se considera colectiva, pertenece al grupo. Surge del consenso y tiene que ser acorde con las creencias e ideales colectivos.

Cuando alguien lo transmite, queriendo preservarlo, lo transforma. Sin embargo, para preservar la transmisión el colectivo se organiza. Al niño se le cuentan los mitos al calor del hogar (ya sean cuentos de nodrizas, fábulas de abuelas o historias de sabedor).

\section{La dificultad de acceder al cuarto nivel}


El principal problema con el que nos encontramos en el análisis interpretativo es que el nivel cuatro no se deja someter a la taxonomía porque es algo interno, algo vital, individual y difícil de transferir (incluso a veces de verbalizar). Pero, que no sea fácilmente accesible al estudioso, no lo convierte en inexistente.

Los habitantes de las ciudades, en culturas con larga tradición escrita, con medios de comunicación, que en buena medida orientan el modo de pensar, quedan alejados de la exposición a ese nivel, a esa experiencia del mito. So

lo en determinadas ocasiones podemos acceder a él y seguramente no del modo que lo hacen los integrantes de la sociedad que generó el mito.

Quizá un ejemplo pueda ser el mito de la ayahuasca que transcribimos según lo recoge Hinostroza (2010, pp. 198-200):

Antes cuando no se conocía el AyahuascaChacuruna, la gente de la Selva de Amazonas vivía muy triste, todo era soledad, enfermedad y muerte; (...) La gente no tenía ojos, oídos, tacto ni olfato para sentir la presencia de las enfermedades y muerte.

Un día, un anciano, preocupado y cansado de tanta desgracia, atacado por la enfermedad de tristeza, angustia y coraje sintió la necesidad de salir a buscar soluciones a sus problemas. Poco a poco, se alejó de su 'maloca' (casa) y se internó en el bosque.

En su caminata encontró un lugar oscuro y silencioso, solo había voces y cantos de aves, el ruido del río, un viento fresco. [N3a] Ahí se detuvo y dijo: "Este es el lugar apropiado para recibir enseñanzas y formas de medicina, por aquí pasan los jaguares, venados, sihuas, anacondas, monos, guacamayas, sajinos, chahuacharis, chullanchaquis, tunchis, y en este lugar los diferentes espíritus de las plantas dialogan". Entonces dijo: "Aquí esperaré". [N2a]

Pasó un día intentando escuchar alguna información o señal de algún animal, vegetal, mineral o de algún espíritu, pero no fue posible. Pasó la noche con cierto cansancio y debilidad, buscó a su alrededor algunas hojas de mapachu, de piri piri, pusanga y mucura. Se untó la cara y el cuerpo con el espíritu de estas hojas y, al día siguiente, continuó con la espera pronunciando de vez en cuando nombres de animales, plantas, piedras y ríos [N3b] y al anochecer solo escuchó el silbido 
del chullanchaqui que le asustó y por su cuerpo pasó frío, calor, angustia, sensaciones de vómitos y jaqueca.

Solo logró superar ese momento al amanecer del tercer día cuando llegaron sus hijos, sus nietos y su mujer con el fin de convencerlo que depusiera su propósito. Él se negó a regresar a casa más bien permaneció relajado aproximadamente una hora, sereno como el jaguar, valiente como el tigrillo.

Su mujer que no le pudo abandonar se quedó cerca de él, ambos sin hablarse ni tocarse, se miraron y pensaron en cómo lograr tener visión, tacto y conocimiento.

Y mientras pasaba el tiempo, el anciano sintió que se transformaba en una planta, sintió que sus pies se hundían. [N4a] De las manos comenzaron a salir hojas, de sus cabellos, lianas y al mismo tiempo su mujer se iba transformando en un hermoso arbusto con abundantes hojas y de sus ojos brotaban bonitas flores blancas y amarillas.

Ambos se habían convertido en plantas que tomarían más tarde el nombre de ayahuasca y chacuruna. [N1a]

Al cuarto día, los familiares de los ancianos al constatar que no regresaban a la comunidad organizaron una comitiva compuesta de varias personas que fueron al lugar donde se encontraban los dos ancianos, y vieron con sorpresa cómo el anciano había sido tragado por la tierra y de su cabeza salían hermosas lianas en forma de soga a las que llamaron 'ayahuasca', y cómo su mujer se había transformado en un hermoso arbusto de hojas verdes y largas con una silueta de animal, mujer, planta. En nada se parecía a un humano y por esta cualidad de desorden la llamaron 'chacuruna'.

La comitiva pasó la noche cantando junto a los transformados intentando verlos nuevamente en su estado normal. Al amanecer, al no conseguirlo, ya muy cansados, designaron a una niña virgen, sin menstruación para que recogiera las hojas de la 'chacuruna' y cortara algunas ramas de la liana 'ayahuasca'.

Hechas estas tareas regresaron a la comunidad muy tristes, deprimidos, con mucho miedo y para tener valentía, llamaban por su nombre a los animales, plantas, minerales de la comunidad. Una vez instalados en la comunidad, escogieron un chomo (una vasija muy 
hermosa). $Y$ en ella colocaron las lianas de la ayahuasca que había cortado la niña, luego las hojas de chacuruna y agregaron agua. [N1b]

Al son de las danzas cocieron todo el día, esa mezcla y en la noche el hijo mayor del anciano y algunos miembros de la comunidad vivieron el cocimiento y a medida que pasaban las horas, empezaron a entonar melodías hermosas y entre risas y llantos empezaron a ver, a sentir, a oír y a tener conocimientos sobre las enfermedades de la gente y de la comunidad.

Entonces muchos nativos de la comunidad que estaban enfermos acudieron a la fiesta y estos hombres empezaron a conocer el origen de sus enfermedades $y$ a sanar. Y así se generalizó el uso y consumo de la ayahuasca en toda la selva de Amazonas.

Observemos solo algunos aspectos incluidos en este mito:

- N1a: La transformación en planta es, a la vez, una forma de resaltar la vinculación de las personas y la naturaleza, y el origen de estas plantas curativas (como en tantas otras culturas).

- N1b: Indicaciones de la preparación de la bebida con ayahuasca y chacuruna, y del uso de los ícaros, los cantos de los chamanes.

- N2a: El comportamiento de la paciencia es una cualidad que hay que cultivar.

- N3a: El lugar describe no solo un paisaje, sino el espacio en el que la persona se puede sentir lo que es: parte de la naturaleza. Tiene que buscar la armonía.

- N3b: Los shipibo y otras culturas hablan a la naturaleza, cantan a los peces, utilizan energía vibracional para comunicarse con la naturaleza en un nivel para nosotros desconocido.

- N4a: En la ceremonia de la ayahuasca uno de los efectos que produce la planta es la relajación muscular hasta un punto en el que se siente hundirse en la tierra. Esta experiencia ha sido vivida por los autores en la cuenca del Ucayali (Perú), una de las pocas ocasiones en que hemos podido aproximarnos a la vivencia de un mito, intuir cuál es el verdadero significado de cuarto nivel (aún conscientes que nuestro condicionante cultural nos mantendrá siempre alejados de ese auténtico nivel de percepción del mito vivo). 


\section{Discusión: Necesidad de la pervivencia de los mitos}

Levi-Strauss (1974) decía: "Hay ciertas cosas que hemos perdido y que deberíamos hacer un esfuerzo por recuperar. Dado el tipo de mundo que vivimos, no creo que podamos reconquistarlas como si nunca las hubiésemos perdido, pero podemos intentar tomar conciencia de su existencia e importancia" (p. 25).

Pese a las diferencias culturales entre las fracciones de humanidad, la mente humana es en todas partes una y la misma, con idénticas capacidades. Las diferencias son fecundas y contribuyen al progreso del género humano. Sin embargo, el riesgo de considerar una cultura como verdadera y las demás como falsas, el sentimiento de superioridad rompe el respeto a la dignidad.

La recuperación de los mitos como vehículo de conocimiento, al menos de las personas que pertenecen a otra cultura, podría incorporarse a los procesos educativos desde la infancia. No como una lectura obligatoria o como una introducción a la habilidad lectoescritora, a la literatura o al entretenimiento, sino como una puerta al conocimiento de los otros. Imaginemos la importancia que puede tener esto en la construcción de la convivencia en comunidades escolares en pueblos de América en las que comparten aula mestizos e indígenas.

Como apunta Walter Goldschmidt, en el prólogo a Las enseñanzas de don Juan, de Carlos Castaneda (1974, pp. 25-26): "La experiencia de mundos ajenos nos lleva a comprender que también nuestro propio mundo es una elaboración cultural. Experimentando otros mundos podemos, entonces, ubicar el nuestro en su valor justo y de ese modo capacitarnos para ver fugazmente cómo deber ser, de hecho, el mundo real."

Los mitos pueden servir como herramienta para la toma de conciencia de la diversidad y mejor conocimiento mutuo, en un contacto entre los pueblos basado en el trato igualitario. Sin embargo, con la globalización, la sociedad que estamos viviendo hoy genera mitos globales: el sueño americano, el progreso, la autoregulación de los mercados, la conveniencia de la competitividad, el consumismo. Su vigencia, su autenticidad son tema de discusión.

La globalización nos lleva al riesgo de una uniformización del pensamiento que atenta contra la pervivencia de la diversidad cultural. En uno de los bucles recursivos tan del gusto del Edgard Morin, la Cultura humana, solo existe porque hay "culturas" específicas. Por tanto, cuando una cultura concreta desaparece, la Cultura (con mayúsculas) se ve mermada (Morin, 2011). Muchas decisiones políticas, empresariales y sociales debilitan o amenazan la forma de vida de comu- 
nidades originarias. Conociendo sus mitos y entendiendo el significado que tienen para su vida, podríamos contribuir a respetarlas, modificando la forma en la que actuamos. Se trata de un patrimonio común de la humanidad y es un patrimonio personal de las culturas que todavía viven los mitos.

\section{Bibliografía}

AlmeidA, I. (2014). Mitos cosmogónicos de los pueblos indígenas del Ecuador. Quito: Abya-Yala.

Bermejo, J. (1979). Introducción a la sociología del mito griego. Madrid: Akal.

Bernabé, A. (1976). Los himnos homéricos. La batracomiomaquia. Madrid: Gredos.

Brown, D. (1991). Human Universals. Nueva York: McGraw-Hill.

Castaneda, C. (1974). Las enseñanzas de don Juan. México: Fondo de Cultura Económica. (Obra original publicada en 1968).

Chaparro, A. (2013). Los cuerpos de la serpiente. Quito: Abya-Yala.

De Cuenca, L.A. (2009). Necesidad del mito. Madrid: Nausícaä. (Obra original publicada en 1976).

Eliade, M. (1967). Lo sagrado y lo profano. Barcelona: Guadarrama (Labor). (Obra original publicada en 1957).

Grote, G. (1867). Histoire de la Gréce. París.

Hinostroza, L. Y Dudet, M. (2010). Shamanismo. Medicina y religión de los pueblos americanos de tradición de alta cultura. Lima: INTAAMPAC.

Jung, C.G. (1983). "Introduzione all'inconscio", en C.-G. Jung (ed.), L'uomo e i suoi simboli. Milán: Raffaello Cortina Editore.

Lloyd, G.E.R. (2012). Being, Humanity and Understanding. Oxford: Oxford University Press.

Losev, A.F. (1998). Dialéctica del mito. Bogotá: Universidad Nacional de Colombia. (Obra original publicada en 1990).

Kirk, G. (1973). El mito: su significado y funciones en las distintas culturas. Barcelona: Barral. (Obra original publicada en 1970). 
Kirk, G. (1984). La naturaleza de los mitos griegos. Barcelona: Argos Vergara. (Obra original publicada en 1974).

LÉVI-STRAUSS, C. (1964). El pensamiento salvaje. México: Fondo de Cultura Económica. (Obra original publicada en 1962).

Lévi-Strauss, C. (1987). Mito y significado. Madrid: Alianza Editorial (cuatro conferencias dictadas en 1977).

López Eire, A. y Velasco, M. del H. (2012). La mitología griega: lenguaje de dioses y hombres. Madrid: Arco Libros.

Morin, E. (2007). Introducción al pensamiento complejo. Barcelona: Gedisa Libros. (Obra original publicada en 1990).

Morin, E. (2011). La vía para el futuro de la humanidad. Barcelona: Paidós.

Quezada, O. (2007). Del mito como forma simbólica. Lima: UNMSM.

Sveiby, K.-E. y Skuthorpe, T. (2006). Treading Lightly. Sidney: Allen \& Unwin.

Ushigua, L. (2006). Tsitsanu. Quito: Kuri Ashpa.

Vernant, J.-P. (1991). Mito y religión en la Grecia antigua. Barcelona: Ariel. (Obra original publicada en 1987). 
Análisis semiológico del mito como patrimonio colectivo e individual en cuatro niveles de interpretación
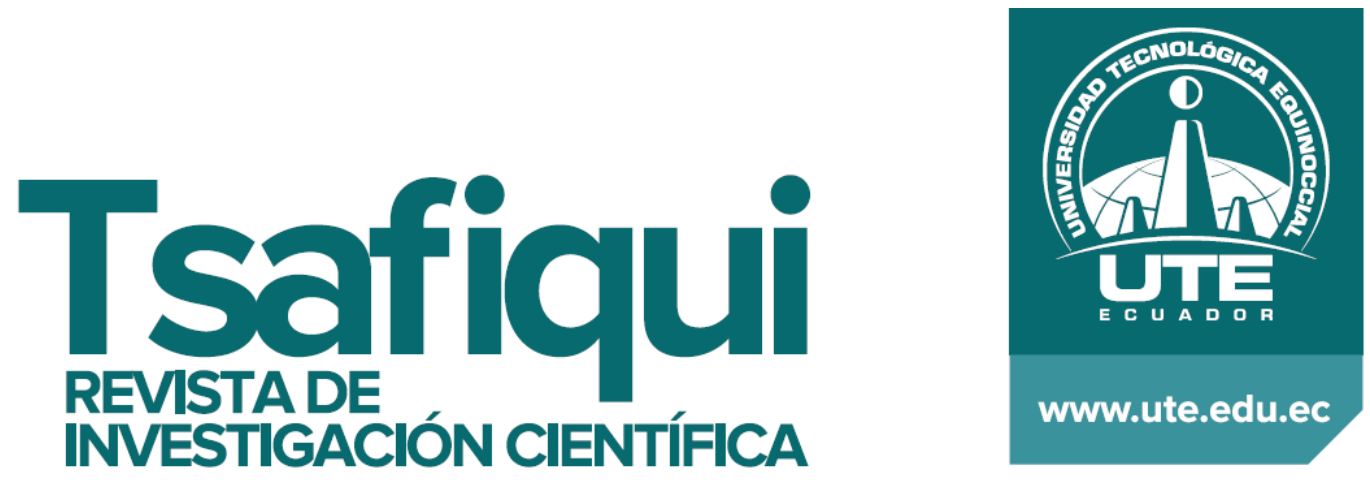